\title{
ACIDITY AND SORPTION PROPERTIES OF ZINC-CONTAMINATED SOIL FOLLOWING THE APPLICATION OF NEUTRALISING SUBSTANCES
}

\author{
Mirosław Wyszkowski ${ }^{1}$, Beata Modrzewska ${ }^{1}$
}

1 Department of Environmental Chemistry, University of Warmia and Mazury in Olsztyn, 4 Łódzki Sq., 10-727 Olsztyn, Poland, e-mail: miroslaw.wyszkowski@uwm.edu.pl

Received: 2015.11.16

Accepted: 2015.12.09

Published: 2016.01.06

\begin{abstract}
Soil plays the most important role in the cycling of elements in the terrestrial environment. Contamination of soil with heavy metals have effect on all soil organism and plants. For this reason, studies have been carried out to assess the possibility of neutralising the effect of zinc $\left(0,150,300,600\right.$ and $1200 \mathrm{mg} \mathrm{Zn} \cdot \mathrm{kg}^{-1}$ of soil) on soil properties by applying neutralising substances (compost, bentonite and zeolite). Soil acidity and sorption properties depended on zinc contamination and on the type of neutralising substances added. In the series without an addition of neutralising substances, increasing zinc soil contamination resulted in a decrease in total exchangeable bases, in cation exchange capacity and in the saturation degree of the degree of base saturation, and an increase in soil hydrolytic acidity. An addition of bentonite to zinc-contaminated soil had the most advantageous effect of all the additions of neutralising substances on the tested soil properties. It resulted in an increase in soil $\mathrm{pH}$, in total exchangeable bases, in cation exchange capacity, in the degree of base saturation and simultaneously decreased soil hydrolytic acidity compared to the series without additions. Adding zeolite and compost to soil had a small and usually insignificant effect on soil acidity and soil sorption properties.
\end{abstract}

Keywords: zinc contamination, compost, bentonite, zeolite, soil properties.

\section{INTRODUCTION}

Air, water and soil are among the most important natural resources [D'Emilio et al. 2012, Massas et al. 2013]. Soil, as an integral element of the natural environment, is a non-renewable resource [Massas et al. 2013]. It also plays the most important role in the cycling of elements in the terrestrial environment [Gorlach, Gambuś 1991] which is constantly subjected to contamination, both with natural and human-induced contaminants [Guala et al. 2013, Massas et al. 2013, Modrzewska, Wyszkowski 2014, Takáč et al. 2009]. Heavy metals are of particular significance. Their excessive concentration is toxic not only for plants, but, through food chain, also for animals and for humans [Esmaeili 2014, Page et al. 2013]. Heavy metals can be bound in soil by changing their forms from readily-soluble to sparingly soluble [Gorlach, Gambuś 1991] which are rare- ly available, or even unavailable, and less toxic to plants and soil organisms [Feng et al. 2007]. Their mobility and availability depends on many factors, of which the most important are soil $\mathrm{pH}$ and soil type, the content and form of the metal in soil, organic matter content, cation exchange capacity, granulometric composition, fertilisation and the contents of macro- and microelements, the species and the variety of plants and, furthermore, soil microorganism activity [Feng et al. 2007, Fijałkowski et al. 2012, Guala et al. 2013, Ociepa 2011, Shaheen, Rinklebe 2014, Takáč et al. 2009, Wyszkowski, Wyszkowska 2009]. Zinc belongs to the group of heavy metals considered to be the most mobile [Fijałkowski et al. 2012] and most sensitive to $\mathrm{pH}$ changes [Sady, Smoleń 2004]. Zinc mobility increases with soil $\mathrm{pH}$ below 6-6.5 [Sady, Smoleń 2004]. Heavy metal mobility is greater in strongly acidified soils compared to soils with neutral and alkaline $\mathrm{pH}$ [Fijałkowski 
et al. 2012, Sady, Smoleń 2004]. Soil pH, together with organic matter, have the greatest effect on the solubility, content and availability of trace elements to plants [Fijałkowski et al. 2012, Ociepa 2011, Sady, Smoleń 2004]. Soil sorption complex sorbs exchangeable heavy metals with different force [Sady, Smolen 2004] and also prevents soil pH fluctuations [Ociepa 2011]. In soils containing clay minerals, as well as in soils with high sorption capacity, trace elements are easily accumulated [Fijałkowski et al. 2012]. Adding to soil mineral and organic substances which allow for increasing sorption capacity, such as: zeolites, bentonites, diatomites, loams, iron oxides and compost or brown coal, contributes to limiting trace elements uptake by plants [Feng et al. 2007, Fijałkowski et al. 2012, Ociepa 2011].

For this reason, studies have been carried out to assess the possibility of neutralising the effect of zinc on soil properties by applying neutralising substances.

\section{MATERIALS AND METHODS}

A study was carried out in the vegetation hall of the University of Warmia and Mazury in Olsztyn (north-eastern Poland) using acidic soil formed from sand. The soil had the following properties: $\mathrm{pH}$ in a $1 \mathrm{~mol} \mathrm{KCl} \cdot \mathrm{dm}^{-3}$ solution -5.32 ; hydrolytic acidity $(\mathrm{HAC})-33.6 \mathrm{mmol}(+) \cdot \mathrm{kg}^{-1}$; total exchangeable bases $\mathrm{Ca}^{++}, \mathrm{Mg}^{++}, \mathrm{K}^{+}$and $\mathrm{Na}^{+}$ (TEB) - $42.1 \mathrm{mmol}(+) \cdot \mathrm{kg}^{-1}$; cation exchange capacity (CEC) $-75.7 \mathrm{mmol}(+) \cdot \mathrm{kg}^{-1}$; base saturation (BS) $-55.6 \%$, the organic-C content -13.8 $\mathrm{g} \cdot \mathrm{kg}^{-1}$; the contents of available forms of: phosphorus $-40.3 \mathrm{mg} \cdot \mathrm{kg}^{-1}$; potassium $-11.9 \mathrm{mg} \cdot \mathrm{kg}^{-1}$ and magnesium - $33.6 \mathrm{mg} \cdot \mathrm{kg}^{-1}$ of soil. The soil was contaminated with the following amounts of zinc: $0,150,300,600$ and $1200 \mathrm{mg} \mathrm{Zn} \cdot \mathrm{kg}^{-1}$ of soil. In order to limit zinc soil contamination, compost $(3 \%)$, bentonite $(2 \%)$ and zeolite $(2 \%$ by weight of the soil) was used. Macro- and microelements were introduced to the soil in all pots, in the same amounts: $30 \mathrm{mg}$ of $\mathrm{N} ; 30 \mathrm{mg}$ of P; $100 \mathrm{mg}$ of $\mathrm{K}$; $50 \mathrm{mg}$ of Mg; $0.33 \mathrm{mg}$ of B; $5 \mathrm{mg}$ of Mn and $5 \mathrm{mg}$ of Mo per $\mathrm{kg}$ of soil. Yellow lupine (Lupinus luteus L.) of the Mistral variety was then sown. Soil samples for laboratory analysis were taken during yellow lupine harvest, at the flowering stage.

The samples were then dried and sieved through a sieve. In the prepared soil, the following properties were analysed: $\mathrm{pH}$ - with potentiometric method, in a $\mathrm{KCl}$ water solution with a concentration of $1 \mathrm{~mol} \cdot \mathrm{dm}^{-3}$. Hydrolytic acidity (HAC) and total exchangeable bases (TEB) were determined with the Kappen method and, on this basis, cation exchange capacity (CEC) was calculated according to the formula: $\mathrm{CEC}=\mathrm{TEB}+\mathrm{HAC}$, and the degree of base saturation (BS) was calculated according to the formula: $\mathrm{BS}=($ TEB $:$ CEC $) \cdot 100$ [Lityński et al. 1976]. The results were statistically analysed with the Statistica software package [StatSoft, Inc. 2014] using a two-way ANOVA analysis of variance. The effects of zinc and neutralising substances on the tested soil properties were assessed using a principal component analysis (PCA). The ratio of variance components was calculated using a two-way ANOVA analysis of variance, with the eta-squared method.

\section{RESULTS AND DISCUSSION}

Soil acidity and sorption properties depended on the zinc contamination and on the type of the neutralising substances added. The results presented in Table 1 indicate that when the dose of zinc was increased to $1,200 \mathrm{mg} \mathrm{Zn} \cdot \mathrm{kg}^{-1}$ of soil, soil $\mathrm{pH}$ decreased. In the series without an addition of neutralising substances, increasing zinc contamination resulted in a decrease in soil $\mathrm{pH}$ from 5.49 to $5.29(\mathrm{r}=-0.643)$ and in an increase in hydrolytic acidity from 16.80 to $22.35 \mathrm{mmol}(+) \cdot \mathrm{kg}^{-1}(\mathrm{r}=-0.933)$. This confirms the study by Guala et al. [2013] in which heavy metal accumulation in plant mass increased with increasing soil acidity and with increasing heavy metal content in soil. Similar conclusions were drawn by Sady and Smoleń [2004], who reported an increase in zinc mobility when soil pH decreased below 6-6.5. Takáč et al. [2009] showed that zinc availability decreases with increasing soil pH. Gorlach and Gambuś [1991] confirmed that with increasing soil $\mathrm{pH}$, the phytotoxic effects of trace elements on plants decreased. With increasing zinc contamination total exchangeable bases $(r=-0.901)$, soil cation exchange capacity $(r=-0.891)$ and base saturation $(\mathrm{r}=-0.956)$ decreased significantly. Sady and Smolen [2004] proved that the higher the cation exchange capacity of the soil is, the more trace elements soil can contain. In their study, the yield of carrot grown on soil with $\mathrm{pH}$ higher than 7.0 and the degree of base saturation higher than $98 \%$ had an acceptable cadmium content. 
Table 1. Effect of zinc contamination on $\mathrm{pH}$ and hydrolitic acidity in soil

\begin{tabular}{|c|c|c|c|c|c|}
\hline \multirow{2}{*}{$\begin{array}{c}\text { Dose of zinc } \\
\text { [mg } \cdot \mathrm{kg}^{-1} \text { of soil] }\end{array}$} & \multicolumn{5}{|c|}{ Kind of substance neutralizing effect of zinc } \\
\hline & without additions & compost & bentonite & zeolite & average \\
\hline \multicolumn{6}{|c|}{$\mathrm{pH}_{\mathrm{KCl}}$} \\
\hline 0 & 5.49 & 5.60 & 6.71 & 5.96 & 5.94 \\
\hline 150 & 5.44 & 5.49 & 6.63 & 5.72 & 5.82 \\
\hline 300 & 5.25 & 5.32 & 6.45 & 5.67 & 5.67 \\
\hline 600 & 5.31 & 5.29 & 6.20 & 5.56 & 5.59 \\
\hline 1200 & 5.29 & 5.27 & 6.06 & 5.43 & 5.51 \\
\hline Average & 5.36 & 5.39 & 6.41 & 5.67 & 5.71 \\
\hline $\mathrm{r}$ & $-0.643^{*}$ & $-0.800^{* *}$ & $-0.954^{* *}$ & $-0.912^{* *}$ & $-0.905^{* *}$ \\
\hline LSD & \multicolumn{5}{|c|}{$a-0.04^{* *}, \quad b-0.04^{* *}, a \cdot b-0.08^{*}$} \\
\hline \multicolumn{6}{|c|}{ Hydrolitic acidity $(\mathrm{HAC})\left[\mathrm{mmol}(+) \cdot \mathrm{kg}^{-1}\right.$ of soil $]$} \\
\hline 0 & 16.80 & 18.15 & 10.65 & 14.25 & 14.96 \\
\hline 150 & 18.30 & 20.40 & 10.35 & 18.15 & 16.80 \\
\hline 300 & 20.10 & 20.85 & 10.80 & 17.85 & 17.40 \\
\hline 600 & 20.55 & 20.40 & 13.05 & 19.35 & 18.34 \\
\hline 1200 & 22.35 & 22.65 & 14.10 & 22.95 & 20.51 \\
\hline Average & 19.62 & 20.49 & 11.79 & 18.51 & 17.60 \\
\hline $\mathrm{r}$ & $0.933^{* *}$ & $0.865^{\star *}$ & $0.946^{* *}$ & $0.940^{* *}$ & $0.969^{* *}$ \\
\hline LSD & \multicolumn{5}{|c|}{$a-0.97^{\star *}, \quad b-0.87^{\star *}, \quad a \cdot b-1.93^{\star *}$} \\
\hline
\end{tabular}

LSD (least squares deviation) for: $\mathrm{a}$ - zinc dose, $\mathrm{b}-$ kind of neutralizing substance, $\mathrm{a} \cdot \mathrm{b}-$ interaction; significant for: ${ }^{* *}-\mathrm{P}=0.01,{ }^{*}-\mathrm{P}=0.05$, n.s. non-significant; $\mathrm{r}$ - correlation coefficient.

Among the applied substances, bentonite had the greatest and most advantageous effect on the tested soil properties (Tables 1, 2). Following its application, an increase in soil $\mathrm{pH}$ by over one unit was observed. Simultaneously, soil hydrolytic acidity decreased by $40 \%$ on average, compared to the series without additions. In addition, average increases in total exchangeable bases (by 140\%), in cation exchange capacity (by 67\%) and in the degree of base saturation (by $27 \%$ ) were reported. A similar effect of bentonite on soil properties was reported by Wyszkowski and Ziółkowska [2011, 2013] and Wyszkowski and Sivitskaya [2015]. Studies by Guala et al. [2013] and Martinez-Alcala et al. [2010] indicate that a change in solum $\mathrm{pH}$ has an effect on metal mobility in soil, as an increase in acidity promotes greater solubility of trace elements. Thus, zinc is more available and more soluble in acidic soils than in alkaline soils [MartinezAlcala et al. 2010, Shaheen, Rinklebe 2014], which translates into greater zinc accumulation in plants [Shaheen, Rinklebe 2014]. However, according to Sady and Smolen [2004], liming does not always have a positive effect on decreasing the contents of available trace elements in soil. They report that in soil with alkaline $\mathrm{pH}$ and with high organic matter content, the mobility of trace elements may increase by creating heavy metal complexes with organic matter. These complexes are both readily available and accessible to plants. Esmaeili et al. [2014] reported that all the heavy metals occurring in agricultural soils significantly correlate with $\mathrm{pH}$ value. In addition, Shaheen and Rinklebe [2014] showed that a high zinc content in soil was correlated with a low $\mathrm{pH}$ value, which was confirmed by the results of this study. The results of the author's own research indicate that adding zeolite and compost to soil had a small, often insignificant, effect on soil acidity and on soil sorption properties, compared to a series without neutralising substances. A similar relation was observed by Ociepa [2011], who found that adding to soil sewage sludges, a mixture of the sludges with brown coal and mineral fertilisation resulted in small changes in $\mathrm{pH}$ value and improved the soil sorption properties to varying degrees.

In a study by Ociepa [2011], sewage sludges and their mixture with brown coal had the most advantageous effect on an increase in total exchangeable bases, in cation exchange capacity and on the degree of base saturation. Sady and Smoleń [2004] also demonstrated that following an introduction of diatomite to soil there was 
Table 2. Effect of zinc contamination on total exchangeable bases, cation exchange capacity and base saturation in soil

\begin{tabular}{|c|c|c|c|c|c|}
\hline \multirow{2}{*}{$\begin{array}{l}\text { Dose of zinc } \\
\text { [mg } \cdot \mathrm{kg}^{-1} \text { of soil] }\end{array}$} & \multicolumn{5}{|c|}{ Kind of substance neutralizing effect of zinc } \\
\hline & without additions & compost & bentonite & zeolite & average \\
\hline \multicolumn{6}{|c|}{ Total exchangeable bases $($ TEB $)\left[\mathrm{mmol}(+) \cdot \mathrm{kg}^{-1}\right.$ of soil $]$} \\
\hline 0 & 44.25 & 42.25 & 91.10 & 36.35 & 53.49 \\
\hline 150 & 39.90 & 42.55 & 83.25 & 32.60 & 49.58 \\
\hline 300 & 24.85 & 31.10 & 71.35 & 29.15 & 39.11 \\
\hline 600 & 20.25 & 20.00 & 57.80 & 17.55 & 28.90 \\
\hline 1200 & 13.80 & 15.70 & 40.15 & 15.85 & 21.38 \\
\hline Average & 28.61 & 30.32 & 68.73 & 26.30 & 38.49 \\
\hline$r$ & $-0.901^{* *}$ & $-0.923^{* *}$ & $-0.982^{* *}$ & $-0.921^{* *}$ & $-0.952^{* *}$ \\
\hline LSD & \multicolumn{5}{|c|}{$a-5.34^{* *}, \quad b-4.78^{* *}, a \cdot b-10.69^{* *}$} \\
\hline \multicolumn{6}{|c|}{ Cation exchange capacity (CEC) $\left[\mathrm{mmol}(+) \cdot \mathrm{kg}^{-1}\right.$ of soil] } \\
\hline 0 & 61.05 & 60.40 & 101.75 & 50.60 & 68.45 \\
\hline 150 & 58.20 & 62.95 & 93.60 & 50.75 & 66.38 \\
\hline 300 & 44.95 & 51.95 & 82.15 & 47.00 & 56.51 \\
\hline 600 & 40.80 & 40.40 & 70.85 & 36.90 & 47.24 \\
\hline 1200 & 36.15 & 38.35 & 54.25 & 38.80 & 41.89 \\
\hline Average & 48.23 & 50.81 & 80.52 & 44.81 & 56.09 \\
\hline$r$ & $-0.891^{* *}$ & $-0.894^{* *}$ & $-0.980^{* *}$ & $-0.836^{* *}$ & $-0.940^{* *}$ \\
\hline LSD & \multicolumn{5}{|c|}{$a-5.68^{* *}, \quad b-5.03^{* *}, \quad a \cdot b-11.37^{\star *}$} \\
\hline \multicolumn{6}{|c|}{ Base saturation (BS) [\%] } \\
\hline 0 & 72.48 & 69.95 & 89.53 & 71.84 & 75.95 \\
\hline 150 & 68.56 & 67.59 & 88.94 & 64.24 & 72.33 \\
\hline 300 & 55.28 & 59.87 & 86.85 & 62.02 & 66.01 \\
\hline 600 & 49.63 & 49.50 & 81.58 & 47.56 & 57.07 \\
\hline 1200 & 38.17 & 40.94 & 74.01 & 40.85 & 48.49 \\
\hline Average & 56.82 & 57.57 & 84.18 & 57.30 & 63.97 \\
\hline$r$ & $-0.956^{\star *}$ & $-0.972^{* *}$ & $-0.995^{\star *}$ & $-0.958^{\star *}$ & $-0.978^{\star *}$ \\
\hline LSD & \multicolumn{5}{|c|}{$a-3.66^{* *}, \quad b-3.27^{* *}, \quad a \cdot b-7.31^{* *}$} \\
\hline
\end{tabular}

LSD (least squares deviation) for: $\mathrm{a}$ - zinc dose, $\mathrm{b}$ - kind of neutralizing substance, $\mathrm{a} \cdot \mathrm{b}-$ interaction; significant for: ${ }^{* *}-\mathrm{P}=0.01,{ }^{*}-\mathrm{P}=0.05$, n.s. non-significant; $\mathrm{r}$ - correlation coefficient.

a decrease in cadmium accumulation in carrot roots, both for soil with natural cadmium content and for cadmium-contaminated soil. As well, a 25-year-long manure fertilisation study showed an increase in the degree of soil saturation with alkaline elements [Sady, Smolen 2004], which greatly limits trace element accumulation in cultivated plants. Gorlach and Gambuś [1991] also indicated the strong participation of the organic part of the soil sorption complex in binding trace elements in the soil. In addition, heavy metal toxicity to maize and radish decreased with increasing soil cation exchange capacity.

In the analysed zinc-contaminated soil, the first two principal components represent $97.14 \%$ of primary variable variance. The first principal component accounts for $92.87 \%$ of the total variance and the second principal component for $4.27 \%$ (Figure 1). All vectors representing the tested soil properties are very well represented by the first two principal components, which form a coordinate system. Most of the vectors, particularly the vectors of total exchangeable bases and of the degree of base saturation, are very strongly slanted towards the nearest first principal component. This proves that their reaction to soil zinc contamination was similar and negative. The opposite relations were observed for soil hydrolytic acidity. The vectors representing the primary variables for the degree of base saturation and $\mathrm{pH}$, for the degree of base saturation and total exchangeable bases, and for total exchangeable bases and soil cation exchange capacity are close to each other, which indicates the relations between them 


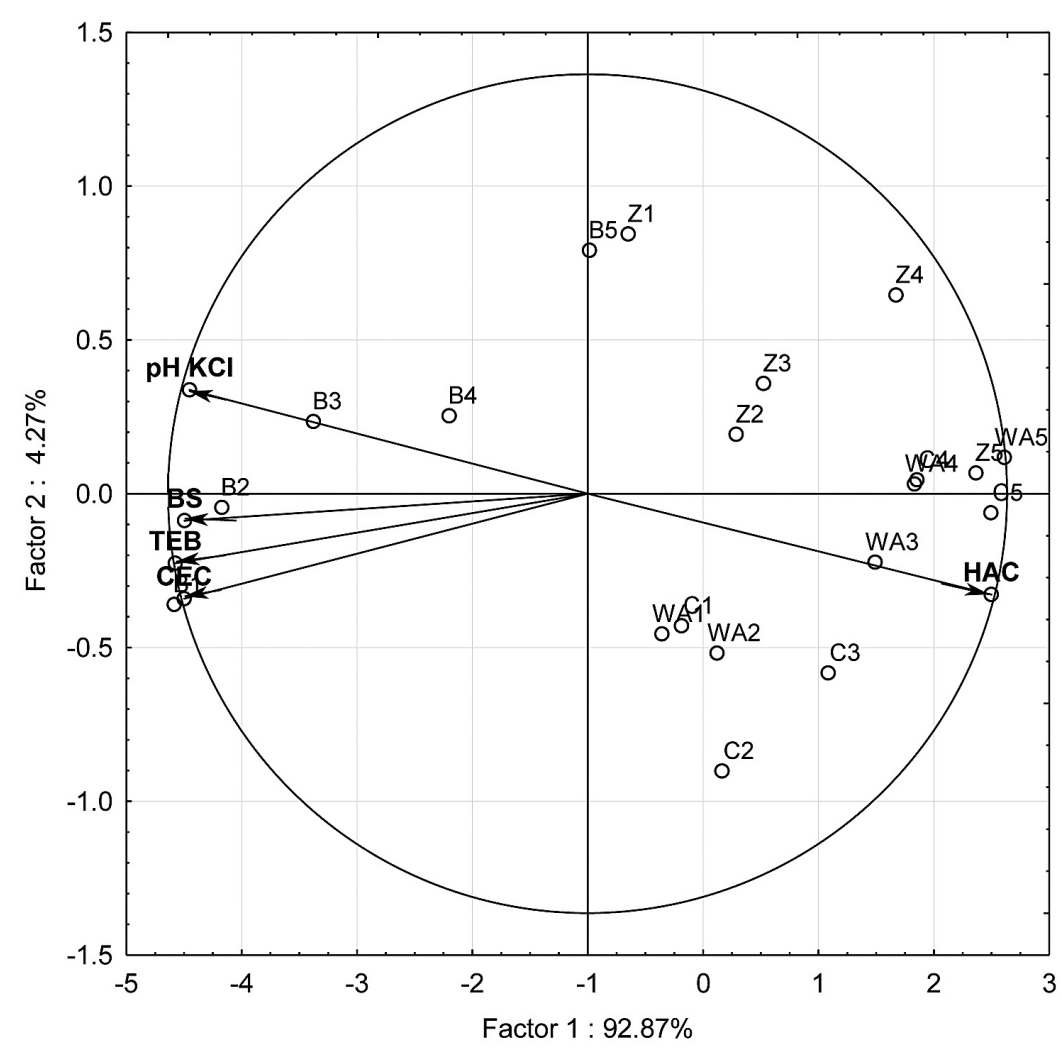

Figure 1. Properties of soil illustrated with the PCA method. Key: vectors represent analyzed variable $\left(\mathrm{pH}_{\mathrm{KCl}}-\mathrm{pH}\right.$ in $1 \mathrm{M} \mathrm{KCL}, \mathrm{HAC}$ - hydrolitic acidity, TEB - total exchange bases, $\mathrm{CEC}$ - cation exchange capacity, BS - base saturation), points show soil samples with elements (WA - without additions, $\mathrm{C}$ - compost,

B - betonite, Z - Zeolite; 1 - 0, 2 - $150 \mathrm{mg}, 3-300 \mathrm{mg}, 4-600 \mathrm{mg}, 5-1200 \mathrm{mg} \mathrm{Zn} \cdot \mathrm{kg}^{-1}$ of soil)

were positive. The vectors between soil hydrolytic acidity and other soil properties, particularly soil $\mathrm{pH}$, were, in turn, very far apart from each other, which represents the negative correlations between these elements.

When the percentage of observed variance was calculated with the coefficient $\eta 2$, using the ANOVA method, it was demonstrated that the tested properties of zinc-contaminated soil were to the greatest extent determined by an application of neutralising substances. This is particularly true for soil $\mathrm{pH}$ and for soil hydrolytic acidity: $85.86 \%$ and $73.76 \%$ of the variance can be explained by this variable, respectively (Table 3 ).
High values were also reported for the other properties, which ranged from $54.70 \%$ (the degree of base saturation) to $64.21 \%$ (total exchangeable bases). The percentage of the variance which could be explained by the second variable, i.e. by zinc soil contamination, was much lower and varied between $11.38 \%\left(\mathrm{pH}_{\mathrm{KCl}}\right)$ and $40.36 \%$ (the degree of base saturation).

A comprehensive study of the mechanisms of bioavailability to plants of trace elements occurring in soil allows for rapid assessment of the risk of food chain contamination, and for choosing the right means to neutralise harmful substances, including heavy metals.

Table 3. Per cent contribution of variable factors according to the soil properties

\begin{tabular}{|l|c|c|c|c|c|}
\hline \multirow{2}{*}{ Variables } & \multicolumn{5}{c|}{ Content in soil } \\
\cline { 2 - 6 } & $\mathrm{pH}_{\mathrm{KCl}}$ & HAC & TEB & CEC & BS \\
\hline Dose & 11.38 & 20.91 & 30.68 & 31.74 & 40.36 \\
\hline Substance & 85.86 & 73.76 & 64.21 & 59.91 & 54.70 \\
\hline Dose substance & 2.57 & 3.86 & 3.61 & 5.96 & 3.60 \\
\hline Error & 0.18 & 1.48 & 1.50 & 2.39 & 1.34 \\
\hline
\end{tabular}

Explanations: $\mathrm{pHKCl}-\mathrm{pH}$ in $1 \mathrm{M} \mathrm{KCL}, \mathrm{HAC}$ - hydrolitic acidity, TEB - total exchange bases, CEC - cation exchange capacity, BS - base saturation. 


\section{CONCLUSIONS}

1. In the series without an addition of neutralising substances, increasing zinc soil contamination resulted in a decrease in total exchangeable bases, in cation exchange capacity and in the saturation degree of the degree of base saturation, and an increase in soil hydrolytic acidity.

2. An addition of bentonite to zinc-contaminated soil had the most advantageous effect of all the additions of neutralising substances on the tested soil properties. It resulted in an increase in soil $\mathrm{pH}$, in total exchangeable bases, in cation exchange capacity, in the degree of base saturation and simultaneously decreased soil hydrolytic acidity compared to the series without additions.

3. Adding zeolite and compost to soil had a small and usually insignificant effect on soil acidity and soil sorption properties.

\section{REFERENCES}

1. D’Emilio M., Caggiano R., Macchiato M., Ragosta M., Sabia S. 2012. Soil heavy metal contamination in an industrial area: analysis of the data collected during a decade. Environmental Monitoring and Assessment, 185(7), 5951-5964.

2. Esmaeili A., Moore F., Keshavarzi B., Jaafarzadeh N., Kermani M. 2014. A geochemical survey of heavy metals in agricultural and background soils of the Isfahan industrial zone, Iran. Catena, 121, 88-98.

3. Feng N., Dagan R., Bitton G. 2007. Toxicological approach for assessing the heavy metal binding capacity of soils. Soil Sediment Contamination, 16, 451-458.

4. Fijałkowski K., Kacprzak M., Grobelak A. Placek A. 2012. The influence of selected soil parameters on the mobility of heavy metals in soils. Inżynieria i Ochrona Środowiska, 15(1), 81-92.

5. Gorlach E., Gambuś F. 1991. Desorpcja i fitotoksyczność metali ciężkich zależne od właściwości gleby. Roczniki Gleboznawcze, XLII(3/4), 207-214.

6. Guala S., Vega Flora A., Covelo E. F. 2013. Modeling the plant-soil interaction in presence of heavy metal pollution and acidity variations. Environmental Monitoring and Assessment., 185, 73-80.

7. Lityński T., Jurkowska H., Gorlach E. 1976. Analiza chemiczno-rolnicza. PWN, Warszawa, 129-132.

8. Martinez-Alcala I., Walker D.J, Bernal M.P. 2010. Chemical and biological properties in the rhi- zosphere of Lupinus albus alter soil heavy metal fractionation. Ecotoxicology and Environmental Safety, 73, 595-602.

9. Massas I., Kalivas D., Ehaliotis C., Gasparatos D. 2013. Total and available heavy metal concentrations in soils of the Thriassio plain (Greece) and assessment of soil pollution indexes. Environmental Monitoring and Assessment, 185(8), 6751-6766.

10. Modrzewska B., Wyszkowski M. 2014. Trace metals content in soils along the State Road 51 (northeastern Poland). Environmental Monitoring and Assessment, 186(4), 2589-2597.

11. Ociepa E. 2011. Wpływ nawożenia na zmianę rozpuszczalności cynku i niklu w glebie oraz pobieranie tych metali przez kukurydzę i ślazowiec pensylwański. Inżynieria i Ochrona Środowiska, 14(1), 41-48.

12. Page V., Weisskopf L., Feler U. 2006. Heavy metals in white lupin: uptake, root-to-shoot transfer and redistribution within the plant. New Phytologist, 171, 329-341.

13. Sady W., Smoleń S. 2004. Wpływ czynników glebowo-nawozowych na akumulację metali ciężkich w roślinach. X Ogólnopolskie Sympozjum Naukowe „Efektywność stosowania nawozów w uprawach ogrodniczych", 269-277.

14. Shaheen S. M., Rinklebe J. 2014. Geochemical fractions of chromium, copper, and zinc and their vertical distribution in floodplain soil profiles along the Central Elbe River, Germany. Geoderma, 228-229, 142-159.

15. StatSoft, Inc. 2014. STATISTICA data analysis software system, version 12. www.statsoft.com.

16. Takáč P., Szabová T., Kozáková L., Benková M. 2009. Heavy metals and their bioavailability from soils in the long-term polluted Central Spiš region of SR. Plant Soil and Environment, 55(4), 167-172.

17. Wyszkowski M., Sivitskaya V. 2015. Effect of different substances on some properties of soil contaminated with heating oil. Journal of Ecological Engineering, 16(1), 62-66.

18. Wyszkowski M., Wyszkowska J. 2009. The effect of contamination with cadmium on spring barley (Hordeum vulgare L.) and its relationship with the enzymatic activity of soil. Fresenius Environmental Bulletin, 18(7), 1046-1053.

19. Wyszkowski M., Ziółkowska A. 2011. Effect of compost, bentonite and $\mathrm{CaO}$ on some properties of soil contaminated with petrol and diesel oil. Ecological Chemistry and Engineering, A, 18 (9-10), 1373-1381.

20. Wyszkowski M., Ziółkowska A. 2013. Compost, bentonite and calcium oxide used for alleviation of the impact of petroleum products on some soil properties. Polish Journal of Natural Sciences, 28(3), 327-337. 